\title{
Digestion of polysaccharides and other major components in the small and large intestine of pigs fed on diets consisting of oat fractions rich in $\boldsymbol{\beta}$-D-glucan
}

\author{
BY KNUD ERIK BACH KNUDSEN, BENT BORG JENSEN \\ AND INGE HANSEN* \\ National Institute of Animal Science, Department of Animal Physiology and Biochemistry, Foulum, \\ PO Box 39, DK-8830 Tjele, Denmark
}

(Received 27 May 1992-Accepted 3 October 1992)

\begin{abstract}
The digestibility of polysaccharides and other major components and the metabolic response of the microflora in the small and large intestines to oat diets varying in mixed linked $\beta(1 \rightarrow 3 ; 1 \rightarrow 4)$-D-glucan $(\beta$-glucan) were studied in experiments with ileum-cannulated pigs. The oat fractions for diets were prepared in a dry milling process in which oat groats were milled into two endosperm fractions (oat flour 1 and oat flour 2) and oat bran. The digestibility of polysaccharides and the metabolic response of the microflora were followed for the two contrasting diets, oat flour 1 and oat bran, from ingestion to excretion while the digestibility of oat groats and oat flour 2 were estimated only at the ileum and in faeces. There was no degradation of $\beta$-glucan from either oat flour 1 or bran in the stomach and the first, middle and distal thirds of the small intestine (average digestibility approximately 0 ), while in the terminal ileum digestibility increased to 0.30 to 0.17 respectively. The digestion of starch in the first third of the small intestine was lower for the high- $\beta$-glucan oat-bran diet $(0.49)$ than for the low- $\beta$-glucan flour diet (0.64). However, digestibility differences between the two diets levelled out as the digesta moved aborally in the small intestine and the digestibility at the terminal ileum was almost complete $(0.970-0.995)$ for all diets. Oat non-starch polysaccharides (NSP) were an easily digestible energy source for the microflora in the large intestine less than $13 \%$ of dietary NSP being recovered in faeces. The bulk of $\beta$-glucan which survived the small intestine was degraded in the caecum and proximal colon while arabinoxylan was more slowly degraded. The amount of residues passing the ileo-caecal junction has little impact on the density of micro-organisms in the large intestine, which on the flour and bran diets were in the range of $10^{10}-10^{11}$ viable counts/g digesta, but a high impact on the activity of the flora in colon. Oat bran resulted in a higher proportion of butyric acid in large intestinal content compared with the flour diet. The faecal bulking effect of oat bran was mainly caused by an increased excretion of protein and fat, presumably of bacterial origin. Of all the diets tested the oat-bran diets had the lowest digestibilities of protein and fat at the terminal ileum and in the faeces.
\end{abstract}

$\beta$-Glucan: Non-starch polysaccharides: Digestibility: Pig

The current public and research interest in oat products, and in oat bran in particular, has its origin in the growing concern among consumers about the relationship between diet and health (Kowalski, 1987). Animal and clinical studies have shown that oat bran, a rich source of soluble dietary fibre (DF; non-starch polysaccharides (NSP) plus lignin) in the form of mixed linked $\beta(1 \rightarrow 3 ; 1 \rightarrow 4)$-D-glucan ( $\beta$-glucan), has a significant potential for improving carbohydrate metabolism and reducing cholesterol levels (Kirby et al. 1981; Chen \& Anderson, 1986; Anderson, 1990). The mechanism(s) for both metabolic responses is uncertain, but model experiments with purified $\beta$-glucan (oat gum) have suggested that

* Present address: Danish Centre for Tropical Agriculture and Environment, The Royal Veterinary and Agricultural University, Rolighedsvej 23, DK-1958 Frederiksberg C. 
lumen viscosity plays an important role through bulk effects and/or by increasing the resistance to diffusion of nutrients through the unstirred water layers (Wood, 1986; Anderson, 1990). However, studies with pigs show that there is no simple relationship between soluble DF in oats and the postprandial glucose and insulin responses (Bach Knudsen et al. 1990). It was found that oat bran added to a diet of wheat flour and rolled oats slows the rise in postprandial blood glucose levels and the insulin response, while the pattern of postprandial changes between wheat flour and rolled oats are about the same (Bach Knudsen et al. 1990) in spite of the latter diet providing three times as much soluble DF. An even more important factor influencing the rate at which glucose, maltose and maltotriose are liberated for absorption could be, therefore, the presence of intact cell-wall materials in the small intestine. The aleurone and subaleurone cell walls, concentrated in the bran fraction, are thick and heavily packed with $\beta$-glucan, whereas the cell walls of the central endosperm are thinner and with a relatively lower concentration of $\beta$-glucan (Wood, 1986). From a cooking experiment we know that only a small proportion of this $\beta$-glucan is fully solubilized (Yiu et al. 1987). If these cell walls are as indispersable when they pass through the small intestine they may act as a barrier against digestive enzymes and potentially reduce the rate and digestibility of starch and other nutrients in the small intestine.

There is now abundant evidence that the various types of DF affect bowel habit in different ways. DF polysaccharides are the main energy substrate for the microflora in the large intestine and studies have shown that the type and amount of residue passing the ileocaecal junction are critical for the pattern of fermentation in the different regions of the large intestine (Bach Knudsen et al. 1991). From the measurements of the ileal-faecal digestibility difference we know that oat DF polysaccharides (rolled oats and oat bran) are an easily fermentable energy source for the microflora in the large intestine and that the bulking properties of oat DF are far lower than those of wheat DF (Bach Knudsen \& Hansen, 1991). The specific site of its digestion within the large intestine and how the pattern of fermentation in the different regions of the large intestine respond to changes in nutrient supply are, however, less well known.

The aim of the present investigation was to study the effect of $\beta$-glucan in oat fractions on digestion and metabolism of polysaccharides and other major components in the small and large intestines of pigs. Variations in $\beta$-glucan and cell wall composition of the diets were obtained by using oat groats, a fine and a coarse flour (endosperm) fraction and oat bran. Pigs were used as experimental animals and they were fitted with a permanent cannula in the terminal ileum. After completion of the digestibility measurements the animals fed on the two contrasting diets (the fine oat flour and oat bran) were slaughtered and samples of digesta were taken at eleven sites for further analysis. Although a comparison of NSP digestion in man and pig (Mathers, 1991) has revealed a considerably higher digestion of NSP in the small intestine of pig than that of man, we have chosen the pig as an experimental model because in terms of digestive physiology this species is closest to man. Of more importance to our decision was the fact that the pig model allows sampling of digesta under controlled conditions from regions of the gastrointestinal tract which in man are inaccessible.

\section{EXPERIMENTAL}

Oat materials. Oat groats were produced in a commercial oat mill (OTA A/S, Nakskov, Denmark) by cleaning, dehulling and steaming whole-grain oats and further separated by dry milling at the research mill of Carlsberg Research Laboratory. The oat groats were milled on a disc mill (UMS Disc Mill; United Milling Systems A/S, Copenhagen, Denmark) and sifted through a centrifugal sifter (UMS Centrifugal Sifter; United Milling 
Table 1. Composition of experimental diets for the digestibility experiments $(\mathrm{g} / \mathrm{kg}$ dry matter)

\begin{tabular}{|c|c|c|c|c|}
\hline Diet... & A & B & $\mathrm{C}$ & D \\
\hline \multicolumn{5}{|l|}{ Ingredients } \\
\hline Oat groats & 898 & - & - & - \\
\hline Oat flour 1 & - & 866 & - & - \\
\hline Oat flour 2 & - & - & 911 & - \\
\hline Oat bran & - & - & - & 941 \\
\hline Whey powder & 70 & 101 & 56 & 26 \\
\hline Vitamin/mineral mixture* & 31 & 32 & 32 & 32 \\
\hline Chromic oxide (marker) & 1 & 1 & 1 & 1 \\
\hline \multicolumn{5}{|l|}{ Composition of diets } \\
\hline Protein $(\mathrm{N} \times 6.25)$ & 122 & 110 & 126 & 139 \\
\hline $\mathrm{HCl}$-fat & 87 & 79 & 93 & 98 \\
\hline Starch & 578 & 598 & 555 & 508 \\
\hline$\beta$-glucan & 34 & 22 & 43 & 64 \\
\hline S-NSP & 46 & 30 & 55 & 72 \\
\hline I-NSP & 34 & 25 & 36 & 54 \\
\hline NSP & 80 & 55 & 91 & 126 \\
\hline Klason lignin $\dagger$ & 9 & 6 & 8 & 15 \\
\hline Dietary fibre & 89 & 61 & 99 & 141 \\
\hline
\end{tabular}

S-NSP, soluble non-starch polysaccharides; I-NSP, insoluble non-starch polysaccharides; NSP, non-starch polysaccharides.

* Provided the following (mg/kg diet); $\mathrm{Ca}_{2}\left(\mathrm{PO}_{4}\right)_{3} 17000, \mathrm{~K}_{2} \mathrm{HPO}_{4} 5700, \mathrm{NaCl} 4000, \mathrm{CaCO}_{3} 2500, \mathrm{FeSO}_{4}, 5 \mathrm{H}_{2} \mathrm{O}$ 212, $\mathrm{ZnO} 85, \mathrm{MnO} 31, \mathrm{CuSO}_{4} \cdot 5 \mathrm{H}_{2} \mathrm{O} 68, \mathrm{KI} 0 \cdot 2, \mathrm{Na}_{2} \mathrm{SeO}_{3} 0 \cdot 6$, retinyl acetate $1 \cdot 1$, cholecalciferol $0 \cdot 02$, DL- $\alpha$ tocopherol 43 , menadione $1 \cdot 7$, riboflavin $3 \cdot 4$, pantothenic acid $8 \cdot 5$, cobalamin 0.02 .

† Residue resistant to $12 \mathrm{~mol} \mathrm{H}_{2} \mathrm{SO}_{4} / 1$ (Theander \& Åman, 1979; Theander \& Westerlund, 1986).

Table 2. Intake $(\mathrm{g} / \mathrm{d})$ of nutrients during the digestibility measurement periods

(Values are means of two digestibility periods (days 8-14 and 22-28); values in parentheses are intended intake)

\begin{tabular}{llclll}
\hline \hline Diet* $\ldots$ & \multicolumn{1}{c}{ A } & B & C & D \\
\hline Protein & $187(282)$ & & $161(292)$ & $195(280)$ & $222(283)$ \\
Fat & 133 & 116 & 144 & 157 \\
Starch & 885 & 878 & 860 & 814 \\
Dietary fibre & 132 & 88 & 147 & 222 \\
\hline \hline
\end{tabular}

* For details of diets, see Table 1.

Systems A/S) into the following fractions $(\mu \mathrm{m}):<350,350-630$ and $>630$. The yield $(\%)$

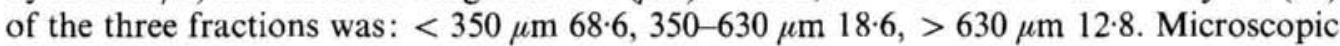
inspection and chemical analysis showed that the fractions $<350 \mu \mathrm{m}$ and $350-630 \mu \mathrm{m}$ were mainly endospermic tissues, while the aleurone and subaleurone tissues were concentrated in the fraction $>630 \mu \mathrm{m}$. For this experiment the three fractions were referred to as oat flour 1, oat flour 2 and oat bran, in order of increasing particle size.

Experimental diets. The experimental diets (Table 1) were prepared from: oat groats (A), oat flour 1(B), oat flour 2(C) and oat bran (D). In the balance periods the diets supplied the amount of nutrients shown in Table 2. It was our intention to make a proper adjustment for the protein content of the diets with casein. However, because of a mislabelling of a bag, whey protein was used rather than casein. The result was a dietary protein intake $(\mathrm{g} / \mathrm{d})$ 
which was $61-129 \mathrm{~g} / \mathrm{d}$ lower than planned. Although this makes direct comparisons between the digestibility measurements of protein difficult, we strongly believe that the lower protein intake had only minor effects on the digestibility measurements of the other nutrients. A rat study in which the protein level of the diets varied from 128 to $521 \mathrm{~g} / \mathrm{kg}$ dry matter (DM) supported this view as the protein level had no effect on the digestibility of DM, energy, starch and DF (Hansen et al. 1991).

Animals and feeding. Crossbred male castrated pigs (National Institute of Animal Science swine herd, Foulum, Denmark) weighing 40-50 kg were used in the present experiment. All pigs were fitted with a permanent cannula at the terminal ileum. Surgery was done at $30-35 \mathrm{~kg}$ and a ' $\mathrm{T}$ ' cannula was placed in the ileum approximately $150 \mathrm{~mm}$ anterior to the ileo-caecal junction. A total of sixteen cannulate pigs was used. The sixteen pigs were divided into four groups (one group/diet) with one littermate from each sow in each group (Bach Knudsen \& Hansen, 1991). The animals were fed three times daily, at 07.00, 15.00 and 23.00 hours, with an amount of DM corresponding to approximately $40 \mathrm{~g} / \mathrm{kg}$ body weight (BW) adjusted to give the same amount of net energy per d (1.8 Feeding Units pigs (FUp), where $1 \mathrm{FUp}$ is $7.7 \mathrm{MJ}$ net energy; Just, 1975 ; BW $45 \mathrm{~kg}$ ). The feed was thoroughly mixed with water before feeding. In the adaptation period lasting $7 \mathrm{~d}$ the pigs were housed individually in $4 \mathrm{~m}^{2}$ smooth-walled pens with a concrete floor. For digestibility measurements the pigs were moved to individual metabolism cages. Faeces were collected quantitatively on days $7-11$ and ileal digesta on days 12-14. To obtain a representative sample of ileal digesta a total collection period of $12 \mathrm{~h}$ was used; on day 12 at $09.00-11.00$ and 13.00-15.00 hours, on day 13 at $08.00-10.00$ and $12.00-14.00$ hours and on day 14 at $07.00-09.00$ and $11.00-13.00$ hours. The whole procedure was repeated with the same pig on days 15-28. After finishing the balance experiment the pigs on diet $\mathbf{B}$ (oat flour 1) and $\mathrm{D}$ (oat bran) were fed for an additional $14 \mathrm{~d}$. In the post-balance period the pigs were fed twice daily, at 07.00 and 15.00 hours. On day 42 the pigs were given the morning ration and killed $4 \mathrm{~h}$ after feeding. Immediately after slaughter, the gastrointestinal (GI) tract was removed and separated by ligatures into eleven sections. These comprised the stomach, three equal segments of the small intestine $\left(\mathrm{SI}_{1}, \mathrm{SI}_{2}, \mathrm{SI}_{3}\right)$, the caecum $(\mathrm{Ce})$ and six segments of the colon $\left(\mathrm{C}_{1}, \mathrm{C}_{2}, \mathrm{C}_{3}, \mathrm{C}_{4}, \mathrm{C}_{5}, \mathrm{C}_{6}\right)$. The latter consisted of the proximal, two ascending, two descending and the distal segments.

Faeces were collected twice daily, frozen and stored at $-20^{\circ}$. At the end of the experiment the faeces were mixed before sampling for analysis. The DM content of the faeces was determined on fresh material taken immediately after the pigs were transferred from the balance cage to the pen. The ileal digesta were collected on ice, frozen immediately after collection, stored at $-20^{\circ}$ and mixed thoroughly before samples were taken for analysis. The total contents of each GI segment were collected carefully and weighed. The samples for analysis of the predominant bacteria were sampled immediately into anaerobic dilution media, while the samples for adenine nucleotides were collected in cold $\mathrm{HClO}_{4}-$ EDTA (PCA/EDTA), mixed and stored at $-80^{\circ}$. The other samples were frozen immediately and stored at $-20^{\circ}$ until required for further analysis

Analytical methods. All analyses were made in duplicate. $\mathrm{N}, \mathrm{Cr}_{2} \mathrm{O}_{3}$, adenosine nucleotides, organic acids (OA) and the bacteriological determinations were performed on wet material; other analyses were carried out on freeze-dried materials. DM contents of feed, digesta and faeces were determined by drying at $105^{\circ}$ to constant weight. Protein $(\mathrm{N} \times 6.25)$ was determined by the Kjeldahl method using a Kjell-Foss 16200 autoanalyser, and energy by an IKA calorimeter C 400 (Janke \& Kunthel KG IKA-Werk, Heitersheim, Germany). Ash was analysed according to the Association of Official Analytical Chemists (1975) while fat (HCl-fat) was extracted with diethyl ether after acid-hydrolysis (Stoldt, 1952). $\mathrm{Cr}_{2} \mathrm{O}_{3}$ was determined using the method of Schürch et al. (1950).

Low-molecular-weight (LMW) sugars (glucose, fructose, sucrose, raffinose) and fructans 
were extracted with acetate buffer $\left(0 \cdot 1 \mathrm{~mol} / 1,65^{\circ}, \mathrm{pH} 5 \cdot 0\right)$. Glucose and fructose residues were quantified with specific enzymes before and after hydrolysis $\left(0.037 \mathrm{~mol} \mathrm{H}_{2} \mathrm{SO}_{4} / 1,80^{\circ}\right.$, 70 min; Larsson \& Bengtsson, 1983). Sucrose was calculated as 1.9 times the total glucose in the hydrolysate minus free glucose. Raffinose in raw materials was determined separately by HPLC using the method of Bach Knudsen \& Li (1991) and total $\beta$-glucan by the enzymic methods of McCleary \& Glennie-Holmes (1985). Starch was analysed by a modification of the enzymic method of Bach Knudsen et al. (1987). Starch was gelatinized and quantitatively removed by incubation $\left(100^{\circ}, 60 \mathrm{~min} ; 60^{\circ}, 16 \mathrm{~h}\right)$ with thermostable $\alpha$ amylase (EC 3.2.1.1; Termamyl ${ }^{\text {B }}$; Novo Nordisk A/S, Copenhagen, Denmark), which at the incubation temperature of $100^{\circ}$ was $\beta$-glucanase-free, and a $\beta$-glucanase-free amyloglucosidase (EC 3.2.1.3; Boehringer Mannheim GmbH, Mannheim, Germany). The resulting glucose monomers were quantified with a glucose oxidase $(E C 1.1 .3 .4)$ reagent (Boehringer Mannheim GmbH). Total NSP and their constituent sugars were determined as alditol acetates by GLC for neutral sugars, and by a colorimetric method for uronic acids using a modification of the Theander \& Aman (1979), Theander \& Westerlund (1986) and Englyst et al. (1982) procedures. The polysaccharides in the starch-free residues, obtained after incubation with thermostable $\alpha$-amylase and $\beta$-glucanase-free amyloglucosidase, were allowed to swell in the presence of $12 \mathrm{~mol} \mathrm{H}_{2} \mathrm{SO}_{4} / 1\left(30^{\circ}, 60 \mathrm{~min}\right)$, hydrolysed with $1 \mathrm{~mol} \mathrm{H}_{2} \mathrm{SO}_{4} / 1\left(100^{\circ}, 2 \mathrm{~h}\right)$ reduced with $\mathrm{KBH}_{4}$ to alcohols and acetylated using 1-methylimidazole to catalyse the reaction; allose was used as internal standard. Soluble NSP (S-NSP) in the starch-free residue was extracted using a phosphate buffer at neutral $\mathrm{pH}\left(0.2 \mathrm{~mol} / 1,100^{\circ}, \mathrm{pH} \mathrm{7.0)}\right.$ and the neutral and acidic sugars in the insoluble NSP (I-NSP) analysed as described previously (Englyst et al. 1982). Cellulose content was calculated as:

$$
\text { cellulose }=\mathrm{NSP}_{\text {glucose }}-\beta \text {-glucan, }
$$

arabinoxylans $(\mathrm{AX})$ as:

$$
\mathrm{AX}=(\text { arabinose }+ \text { xylose }+ \text { uronic acids }),
$$

and S-NSP as:

$$
\text { S-NSP }=\text { Total-NSP }- \text { I-NSP }
$$

Klason lignin was measured gravimetrically as the residue resistant to $12 \mathrm{~mol} \mathrm{H}_{2} \mathrm{SO}_{4} / 1$ (Theander \& Åman, 1979; Theander \& Westerlund, 1986).

Total lactic acids (LA; D- and L-isomers) were determined by specific enzymes in a coupled enzymic reaction with $\mathrm{NAD}^{+}$and total short-chain fatty acids (SCFA) by GLC as described by Bach Knudsen \& Hansen (1991). The concentration of adenine nucleotides, (ATP, ADP and AMP) in digesta contents was estimated by the luciferin-luciferase (EC 1.13.12.7) method modified as described by Bach Knudsen et al. (1991). The ratio between adenine nucleotides in digesta was expressed as the adenylate energy charge (AEC) and calculated as:

$$
\mathrm{AEC}=\frac{(\mathrm{ATP}+1 / 2 \mathrm{ADP})}{(\mathrm{ATP}+\mathrm{ADP}+\mathrm{AMP})}
$$

Total viable anaerobic bacteria were determined in the following way. Intestinal contents $(10 \mathrm{~g})$ were rapidly collected under a flow of $\mathrm{CO}_{2}$ into flasks containing $90 \mathrm{ml}$ anaerobic dilution solution. This suspension was transferred to $\mathrm{CO}_{2}$-flushed plastic bags and held under $\mathrm{CO}_{2}$ for $2 \mathrm{~min}$. Then 10 -fold dilutions were made in anaerobic dilution solution using the Hungate technique as described by Miller \& Wolin (1974). Samples $(0.5 \mathrm{ml})$ were removed and inoculated into $4.5 \mathrm{ml}$ RCM agar (Merck, Darmstadt, Germany) supplemented with additional agar $(5 \mathrm{~g} / 1)$, hemin $(5 \mathrm{mg} / 1)$ and vitamin $\mathrm{K}_{1}(1 \mathrm{mg} / \mathrm{l})$ in roll tubes in duplicate under an atmosphere of $\mathrm{CO}_{2}$. The roll tubes were then incubated at $38^{\circ}$ for $7 \mathrm{~d}$ and the total anaerobic counts determined.

Calculations and statistical analyses. The content of polysaccharide residues was 
calculated as anhydrosugars, and all recoveries, digestibilities and flow measurements were calculated relative to the insoluble marker $\left(\mathrm{Cr}_{2} \mathrm{O}_{3}\right)$ content:

$$
\text { digestibility of } \mathrm{X}=1-\frac{\mathrm{Cr}_{2} \mathrm{O}_{3(\mathrm{~d})} \times \mathrm{X}_{(\mathrm{I} / \mathrm{F} / \mathrm{S})}}{\mathrm{Cr}_{2} \mathrm{O}_{3(\mathrm{I} / \mathrm{F} / \mathrm{S})} \times \mathrm{X}_{(\mathrm{d})}}
$$

where $X$ is the nutrient in question. $X_{(d)}$ and $X_{(I / F / S)}$ are the concentrations of specific nutrients in the diet (d) and in ileal (I), faecal (F) and in digesta samples $\left(\mathrm{S}=\mathrm{Ce}, \mathrm{C}_{1}, \mathrm{C}_{2}\right.$, $\mathrm{C}_{3}, \mathrm{C}_{4}, \mathrm{C}_{5}$ and $\mathrm{C}_{6}$ ) from different segments of the $\mathrm{GI}$ tract. When calculating starch digestibility it was assumed that free glucose in ileal digesta was derived from starch. The flow of nutrient $\mathrm{X}$ was calculated as:

$$
\text { flow of } \mathrm{X}=\frac{\mathrm{Cr}_{2} \mathrm{O}_{3(\mathrm{~d})} \times \mathrm{X}_{(\mathrm{r} / \mathrm{F} / \mathrm{S})}}{\mathrm{Cr}_{2} \mathrm{O}_{3(\mathrm{I} / \mathrm{F} / \mathrm{s})} \times \mathrm{X}_{(\mathrm{d})}} \times \mathrm{X}
$$

where $\mathrm{X}$ is expressed in $\mathrm{g} / \mathrm{d}$. Flow of organic acids (OA; LA and SCFA) was calculated on the basis of the flow of wet materials at the ileum and in the faeces multiplied by the concentrations of OA (Bach Knudsen \& Hansen, 1991).

The net disappearance of nutrients within the various segments $\left(\mathrm{Ce}, \mathrm{C}_{1}, \mathrm{C}_{2}, \mathrm{C}_{3}, \mathrm{C}_{4}, \mathrm{C}_{5}\right.$ and $\mathrm{C}_{6}$ ) and over the entire large intestine was calculated on the basis of the daily flow of the specific nutrients at the various sampling points. Hence, the net disappearance of, for example, nutrient $\mathrm{X}$ in caecum was calculated as:

$$
\Delta \text { Caecum }=\left(\frac{\mathrm{Cr}_{2} \mathrm{O}_{3(\mathrm{~d})} \times \mathrm{X}_{(\mathrm{I})}}{\mathrm{Cr}_{2} \mathrm{O}_{3(\mathrm{l})}} \times \mathrm{X}_{(\mathrm{d})}-\frac{\mathrm{Cr}_{2} \mathrm{O}_{3\{\mathrm{~d})} \times \mathrm{X}_{(\mathrm{Ce})}}{\mathrm{Cr}_{2} \mathrm{O}_{3(\mathrm{Ce})} \times \mathrm{X}_{(\mathrm{d})}}\right) \times \mathrm{X} .
$$

The results from the balance experiment were initially examined by a two-way analysis of variance model (Snedecor \& Cochran, 1973):

$$
\mathrm{X}_{i j k}=\mu+\alpha_{i}+\beta_{j}+(\alpha \beta)_{i j} \times \epsilon_{i j k},
$$

where $x_{i j k}$ is the dependent variable (i.e. NSP constituent sugar values etc.), $\mu$ is the overall mean, $\alpha_{i}$ is the effect of diet, $\beta_{j}$ is the effect of period and $\epsilon_{i j k}$ is a normally distributed random variable. However, since no period or interaction effects were identified these were omitted from the model and included in the estimate of error $\left(\epsilon_{i j k}\right)$. Significant differences between means were identified by Student-Newman-Keuls multiple-comparison procedure (Snedecor \& Cochran, 1973).

The results from the slaughter experiment were presented as means with their standard errors calculated for each group. Significant differences between diets within each segment were identified by one-way analysis of variance.

All statistical calculations were done by general linear modelling using a SuperANOVA package (Abacus Concepts, Berkeley, CA, USA).

\section{RESULTS}

\section{Chemical composition of oat fractions}

The oat fractions produced from oat groats by dry milling had a low content of Klason lignin (7-22 g/ $\mathrm{kg} \mathrm{DM}$ ) but varied in starch content from 520 to $712 \mathrm{~g} / \mathrm{kg} \mathrm{DM}$ and in NSP content from 48 to $129 \mathrm{~g} / \mathrm{kg} \mathrm{DM}$ (Table 3 ). The main NSP were $(\mathrm{g} / \mathrm{kg} \mathrm{NSP}) \beta$-glucan $(460-590)$ and AX (320-440) while cellulose $(70-80)$ was only a minor component. The $\beta-$ glucan: AX ratio increased from 1.05 in oat flour 1 , to 1.85 in oat bran. The starch concentration was inversely related to NSP, protein and fat as a result of the distribution of cell tissues between fractions. Oat flour 1 consisted mainly of endospermal tissues as indicated by its high starch and low DF contents. The highest concentration of aleurone and subaleurone tissues was found in the bran fraction (oat bran). 
Table 3. Chemical composition of the oat fractions in the diets $(\mathrm{g} / \mathrm{kg}$ dry matter) (Values in parentheses are soluble-NSP)

\begin{tabular}{|c|c|c|c|c|}
\hline & $\begin{array}{c}\text { Oat } \\
\text { groats }\end{array}$ & $\begin{array}{c}\text { Oat } \\
\text { flour } 1\end{array}$ & $\begin{array}{c}\text { Oat } \\
\text { flour } 2\end{array}$ & $\begin{array}{c}\text { Oat } \\
\text { bran }\end{array}$ \\
\hline Protein $(\mathrm{N} \times 6.25)$ & 133 & 111 & 138 & 156 \\
\hline $\mathrm{HCl}$-fat & 98 & 90 & 103 & 110 \\
\hline \multicolumn{5}{|l|}{ LMW-sugars } \\
\hline Monosaccharides & 1 & $<1$ & 1 & 1 \\
\hline Sucrose & 10 & 8 & 13 & 13 \\
\hline Raffinose & 2 & 2 & 2 & 2 \\
\hline Total sugars & 13 & 11 & 16 & 16 \\
\hline Starch & 612 & 712 & 594 & 520 \\
\hline \multicolumn{5}{|l|}{ NSP } \\
\hline Cellulose & 6 & 4 & 5 & 8 \\
\hline$\beta$-glucan & $38(32)$ & $22(19)$ & $51(41)$ & $76(72)$ \\
\hline AX & $28(10)$ & $21(8)$ & $33(12)$ & $41(22)$ \\
\hline Arabinose & $10(2)$ & $7(2)$ & $12(3)$ & $14(7)$ \\
\hline Xylose & $11(3)$ & $7(1)$ & $14(4)$ & $17(8)$ \\
\hline Uronic acids & $7(5)$ & $7(5)$ & $8(5)$ & $10(7)$ \\
\hline Total NSP & $75(43)$ & $48(27)$ & $93(54)$ & $129(99)$ \\
\hline Klason lignin* & 20 & 7 & 15 & 22 \\
\hline Dietary fibre & 95 & 56 & 108 & 151 \\
\hline
\end{tabular}

HCl-fat, hydrochloric acid-fat; LMW-sugars, low-molecular-weight sugars; NSP, non-starch polysaccharides; AX, arabinoxylans.

* Residue resistant to $12 \mathrm{~mol} \mathrm{H}_{2} \mathrm{SO}_{4} / 1$ (Theander \& Åman, 1979; Theander \& Westerlund, 1986).

The $\beta$-glucan content had a great impact on the solubility of DF in the oat fractions. Soluble DF (g/kg total DF) varied from 480 in oat flour 1 to 660 in oat bran.

\section{Digestibility at terminal ileum and in faeces}

Digestibility of polysaccharides. Starch was almost completely digested at the end of the small intestine with values varying from 0.970 to 0.995 (Table 4). The digestibility of NSP was also significant at this site of the GI tract with values in the range $0 \cdot 11-0 \cdot 21$. The NSP digested to the greatest extent was $\beta$-glucan with digestibility values of $0 \cdot 17-0 \cdot 31$. By contrast, AX was almost completely recovered in ileal effluent.

The digestion of NSP in the large intestine was significant with digestibility values above 0.87 . While the digestibilities of starch and $\beta$-glucan were approximately 1.00 the digestibility of $\mathrm{AX}$ was lower at about 0.83 .

Digestibilities of energy, protein and fat. Ileal and faecal digestibilities of energy, protein and fat generally followed the same pattern, with each being negatively correlated with the intake of DF (Table 5). The higher intake of DF with diet D $(222 \mathrm{~g} \mathrm{DF} / \mathrm{d})$ resulted in a significantly lower digestibility at the terminal ileum than with diet $\mathrm{B}(88 \mathrm{~g} \mathrm{DF} / \mathrm{d})$. For diets $\mathrm{B}$ and $\mathrm{D}$ the digestibilities at the terminal ileum were respectively: energy $0.858,0.746$; protein $0.749,0.666$; fat $0.784,0.581$. When measured in faeces the digestibilities of the three constituents for diets $B$ and D respectively were: energy $0.932,0.859$; protein 0.839 , 0.747 ; fat $0.828,0.640$.

Flow of nutrients at the terminal ileum and in faeces. The flow of wet and dry materials at the terminal ileum was mainly regulated by the DF intake and varied between 2083 and $4419 \mathrm{~g}$ wet materials/d and 211 and $441 \mathrm{~g} \mathrm{DM} / \mathrm{d}$ for diet B and D respectively (Table 6). Carbohydrates, particularly NSP, were the dominating constituents of ileal DM effluents ranging from $71 \mathrm{~g} / \mathrm{d}$ with diet $\mathrm{B}$ to $180 \mathrm{~g} / \mathrm{d}$ with diet $\mathrm{D}$. A higher flow of protein and fat 
Table 4. Digestibility of polysaccharides at the ileum and in faeces of pigs fed on diets composed of various oat fractions

(Mean values for four pigs)

\begin{tabular}{|c|c|c|c|c|c|}
\hline $\operatorname{Diet}^{*} \ldots$ & A & B & $\mathrm{C}$ & D & SEM \\
\hline \multicolumn{6}{|l|}{ Ileum } \\
\hline Starch & $0.970^{\mathrm{b}}$ & $0.986^{a}$ & $0.985^{\mathrm{a}}$ & $0.989^{\mathrm{a}}$ & 0.002 \\
\hline NSP & 0.21 & 0.25 & $0-24$ & $0 \cdot 15$ & 0.052 \\
\hline Total glucose & $0 \cdot 31$ & 0.32 & 0.30 & 0.20 & 0.073 \\
\hline$\beta$-glucan & 0.28 & $0 \cdot 30$ & $0 \cdot 31$ & 0.17 & 0.071 \\
\hline $\mathrm{AX}^{3}$ & 0.02 & 0.07 & 0.06 & $0 \cdot 11$ & 0.067 \\
\hline Arabinose & -0.03 & 0.03 & 0.08 & 0.08 & 0.067 \\
\hline Xylose & -0.03 & 0.01 & 0.16 & 0.00 & 0.060 \\
\hline Uronic acids & 0.07 & 0.14 & 0.20 & $0 \cdot 15$ & 0.076 \\
\hline I-NSP & $0 \cdot 11$ & 0.17 & $0 \cdot 13$ & $0 \cdot 18$ & 0.064 \\
\hline S-NSP & 0.31 & 0.36 & $0 \cdot 36$ & $0 \cdot 16$ & 0.058 \\
\hline \multicolumn{6}{|l|}{ Faeces } \\
\hline Starch & $1 \cdot 00$ & 1.00 & 1.00 & 1.00 & - \\
\hline NSP & $0 \cdot 88$ & 0.87 & 0.87 & 0.90 & 0.011 \\
\hline Total glucose & 0.92 & 0.92 & 0.93 & 0.94 & 0.008 \\
\hline$\beta$-glucan & 1.00 & $1 \cdot 00$ & 1.00 & 1.00 & - \\
\hline $\mathrm{AX}$ & 0.82 & 0.82 & 0.82 & 0.83 & 0.013 \\
\hline Arabinose & $0 \cdot 84^{\mathrm{ab}}$ & $0.81^{\mathrm{b}}$ & $0.83^{\mathrm{ab}}$ & $0 \cdot 86^{\mathrm{a}}$ & 0.009 \\
\hline Xylose & $0 \cdot 82$ & 0.86 & 0.80 & 0.79 & 0.025 \\
\hline Uronic acids & 0.82 & 0.86 & 0.80 & 0.78 & 0.025 \\
\hline I-NSP & 0.77 & 0.76 & 0.76 & 0.79 & 0.017 \\
\hline S-NSP & 0.97 & 0.96 & 0.96 & 0.98 & 0.005 \\
\hline
\end{tabular}

$\mathrm{a}, \mathrm{b}$ Values in the same row with unlike superscript letters were significantly different $(P<0.05)$.

NSP, non-starch polysaccharides; AX, arabinoxylans; I-NSP, insoluble non-starch polysaccharides; S-NSP, soluble non-starch polysaccharides.

* For details of diets, see Tables 1 and 3 .

Table 5. Apparent ileal $(I)$ and faecal $(F)$ digestibilities of energy, protein and fat for pigs fed on diets composed of various oat fractions

(Mean values for four pigs)

\begin{tabular}{|c|c|c|c|c|c|c|}
\hline \multirow[b]{2}{*}{ Diet* } & \multicolumn{2}{|c|}{ Energy } & \multicolumn{2}{|c|}{ Protein } & \multicolumn{2}{|c|}{ Fat } \\
\hline & I & $\mathrm{F}$ & I & $\mathrm{F}$ & I & $\mathrm{F}$ \\
\hline A & $0 \cdot 801^{\mathrm{b}}$ & $0-895^{\mathrm{b}}$ & $0 \cdot 723^{\mathrm{ab}}$ & $0.803^{\mathrm{ab}}$ & $0.646^{\mathrm{b}}$ & $0.695^{\circ}$ \\
\hline B & $0.858^{\mathrm{a}}$ & $0.932^{\mathrm{a}}$ & $0.749^{a}$ & $0.839^{\mathrm{a}}$ & $0.784^{a}$ & $0.828^{\mathrm{a}}$ \\
\hline C & $0 \cdot 810^{\mathrm{b}}$ & $0.885^{b}$ & $0.725^{\mathrm{ab}}$ & $0.790^{\mathrm{ab}}$ & $0.731^{a}$ & $0.710^{\mathrm{b}}$ \\
\hline $\mathrm{D}$ & $0 \cdot 744^{\mathrm{c}}$ & $0.859^{\mathrm{b}}$ & $0.666^{\mathrm{b}}$ & $0.747^{\mathrm{b}}$ & $0.581^{\mathrm{b}}$ & $0.640^{\circ}$ \\
\hline SEM & 0.012 & $0 \cdot 011$ & 0.020 & 0.021 & 0.024 & 0.031 \\
\hline
\end{tabular}

$a, b, c$ Values in the same column with unlike superscript letters were significantly different $(P<0 \cdot 05)$.

* For details of diets, see Tables 1 and 3 .

through the terminal ileum resulted from a higher DF intake. With the most refined oatflour diet (diet B), flows of protein and fat were 40 and $25 \mathrm{~g} / \mathrm{d}$ respectively, while with the oat bran diet (diet D) the corresponding values were 74 and $65 \mathrm{~g} / \mathrm{d}$ for these two constituents.

LMW-sugars, starch and most NSP were broken down in the large intestine with only 
DIGESTIBILITY OF OATS IN PIGS

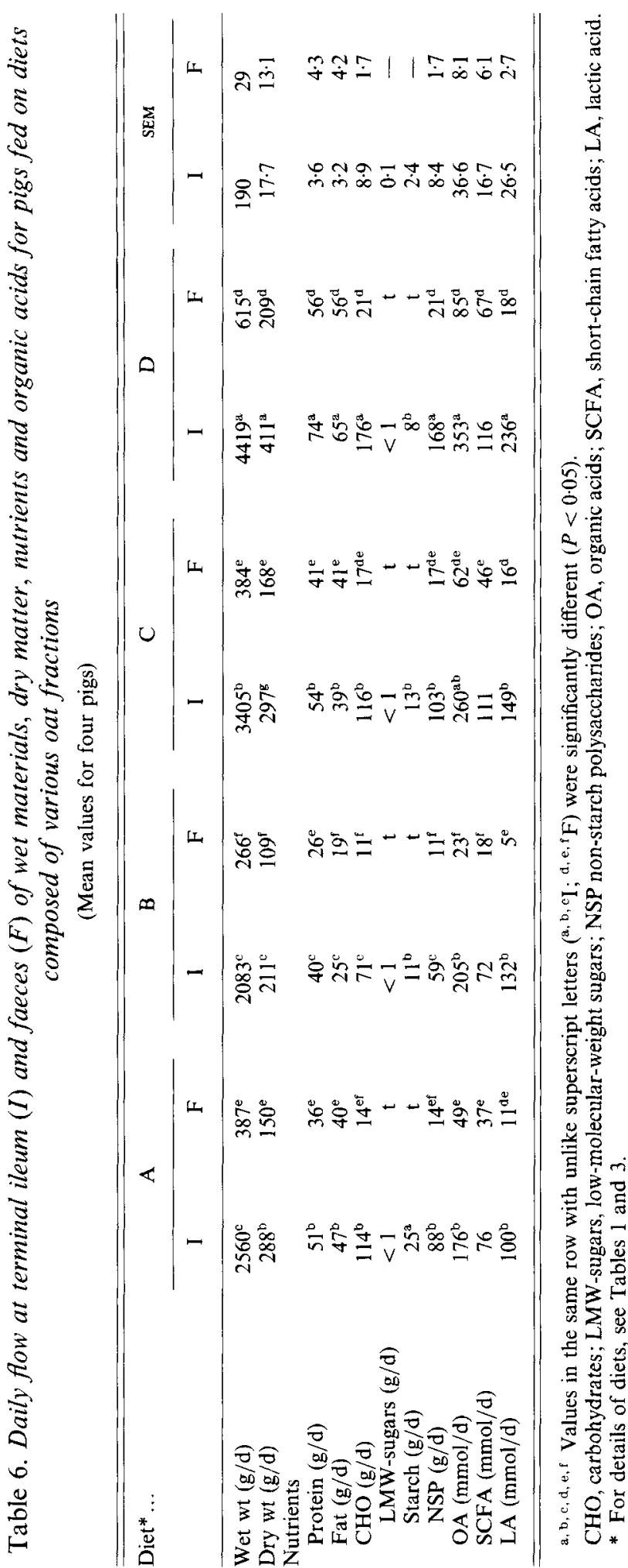




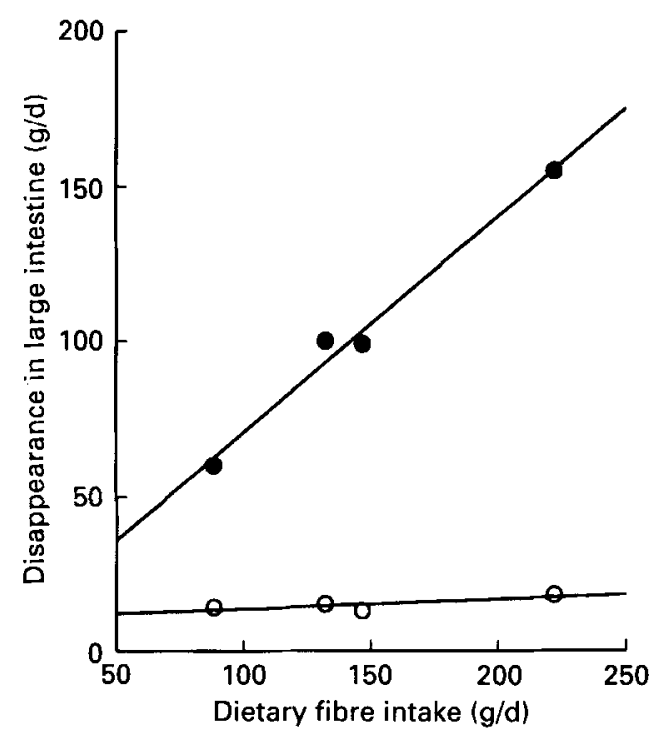

Fig. 1. Correlation between dietary fibre intake and net disappearance of carbohydrates $(O)$ and protein $(O)$ in the large intestine of pigs fed on diets composed of different oat fractions. The points are means of the difference in the flow at the ileum and in the faeces of four pigs. The regression equations are: carbohydrates $(\boldsymbol{O})(\mathrm{g} / \mathrm{d})=$ $1.05+0.70( \pm 0.063) \times$ dietary fibre, $\mathrm{R}^{2} 0.976$ and protein $(\mathrm{O})(\mathrm{g} / \mathrm{d})=10 \cdot 5+0.031( \pm 0.017) \times$ dietary fibre, $R^{2} 0.62$. For details of diets, see Tables 1 and 3.

4-21 g NSP/d being recovered in faecal materials. Hence, net disappearance of carbohydrates in the large intestine was highly correlated with DF intake (Table 6, Fig. 1). In contrast, net disappearance of fat (from -2 to $9 \mathrm{~g} / \mathrm{d}$; Table 6) and protein (12-18 g/d) in the large intestine was independent of DF level (Table 6, Fig. 1).

The daily flow of OA in digesta was $176-353 \mathrm{mmol} / \mathrm{d}$ with a LA: SCFA ratio of $1 \cdot 32-2 \cdot 03$. The flow of OA was primarily determined by the flow of wet materials. The OA concentrations were reasonably constant with values in the range: LA $34-71 \mathrm{mmol} / \mathrm{l}$, SCFA $15-38 \mathrm{mmol} / 1$.

OA excreted in faeces was only $6-28 \%$ of that passing the ileum, with SCFA accounting for more than $75 \%$ of OA.

Bulking properties. A higher DF intake caused an increase in faecal bulk from 266 (diet B) to $615 \mathrm{~g} / \mathrm{d}$ (diet D) and in faecal DM from 109 to $209 \mathrm{~g} / \mathrm{d}$ for the same two diets (Table 6). Protein and fat were the main constituents of faecal DM while DF residues made only a minor contribution to faecal dry material.

\section{Digestibility in small and large intestine}

Digestibility of polysaccharides in small intestine. There was no digestion of starch in the stomach, while there was a significant degradation of starch in the proximal small intestine $\left(\mathrm{SI}_{1}\right.$; Table 7). At this site the digestion of starch was lower for the coarse bran diet (diet $\mathrm{D} ; 0.49$ ) compared with the refined flour diet (diet B; 0.64). However, the difference between the two diets narrowed in the middle and distal portions of the small intestine. Digestibility of $\beta$-glucan was low in the stomach and small intestine with digestibility values varying from 0.19 to -0.20 (Table 7 ). The estimated digestibility of $\beta$-glucan was more variable than that seen for starch. Although there was a significant difference in the digestibility of $\beta$-glucan between the two diets in the stomach and $\mathrm{SI}_{2}$, the difference was not consistent and average digestibility values of $\beta$-glucan in stomach and the three small 
Table 7. Digestibility of starch and $\beta$-glucan in the stomach, first, middle and last thirds of the small intestine, the terminal ileum and caecum of pigs fed on diets composed of various oat fractions

(Mean values for four pigs)

\begin{tabular}{|c|c|c|c|c|c|c|}
\hline \multirow[b]{2}{*}{ Diet* ... } & \multicolumn{3}{|c|}{ Starch } & \multicolumn{3}{|c|}{$\beta$-glucan } \\
\hline & B & $\mathrm{D}$ & SEM & B & $\mathrm{D}$ & SEM \\
\hline Stomach & 0.00 & $-0 \cdot 10$ & 0.051 & $0 \cdot 19^{\mathrm{b}}$ & $-0 \cdot 07^{a}$ & 0.060 \\
\hline Small intestine 1 & $0.64^{\mathrm{b}}$ & $0.49^{\mathrm{a}}$ & 0.037 & -0.07 & $-0 \cdot 11$ & $0 \cdot 136$ \\
\hline Small intestine 2 & 0.95 & 0.90 & $0 \cdot 026$ & $-0.20^{\mathrm{a}}$ & $-0.08^{b}$ & 0.048 \\
\hline Small intestine 3 & 0.98 & 0.98 & $0 \cdot 003$ & -0.02 & 0.17 & 0.118 \\
\hline Ileum & 0.99 & 0.99 & 0.001 & $0 \cdot 30$ & 0.17 & 0.071 \\
\hline Caecum & $>0.99$ & $>0.99$ & 0.001 & 0.99 & 0.92 & 0.033 \\
\hline
\end{tabular}

a, b Values in the same horizontal row for starch and for $\beta$-glucan with unlike superscript letters were significantly different $(P<0.05)$.

Small intestine 1, small intestine 2 and small intestine 3, first, middle and last thirds of the small intestine.

* For details of diets, see Tables 1 and 3 .
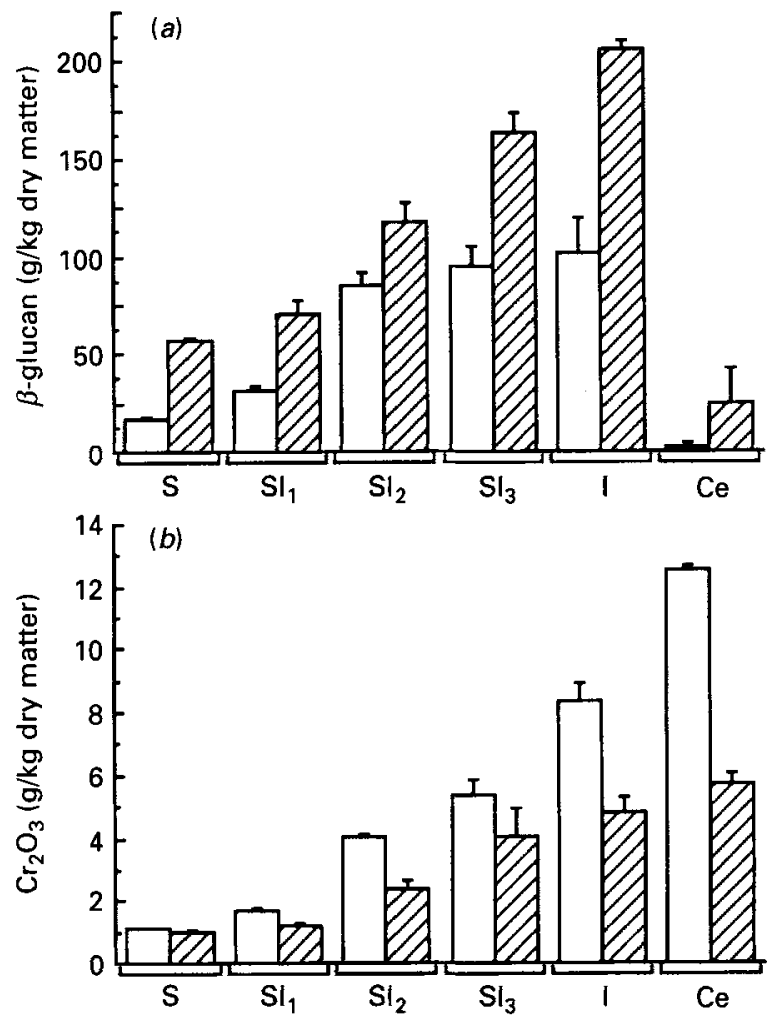

Fig. 2. (a) $\beta$-glucan and (b) chromic oxide marker concentrations ( $\mathrm{g} / \mathrm{kg}$ dry matter) in the gastrointestinal content of pigs fed on oat flour $1(\square)$ and oat bran $(\square)$ diets. The various segments of the gastrointestinal tract were: $S$, stomach; $\mathrm{SI}_{1}, \mathrm{SI}_{2}$, and $\mathrm{SI}_{3}$, three equal segments of the small intestine; I, ileum; Ce, caecum. Values are means of four pigs with their standard errors of means represented by vertical bars. For details of diets, see Tables 1 and 3. 


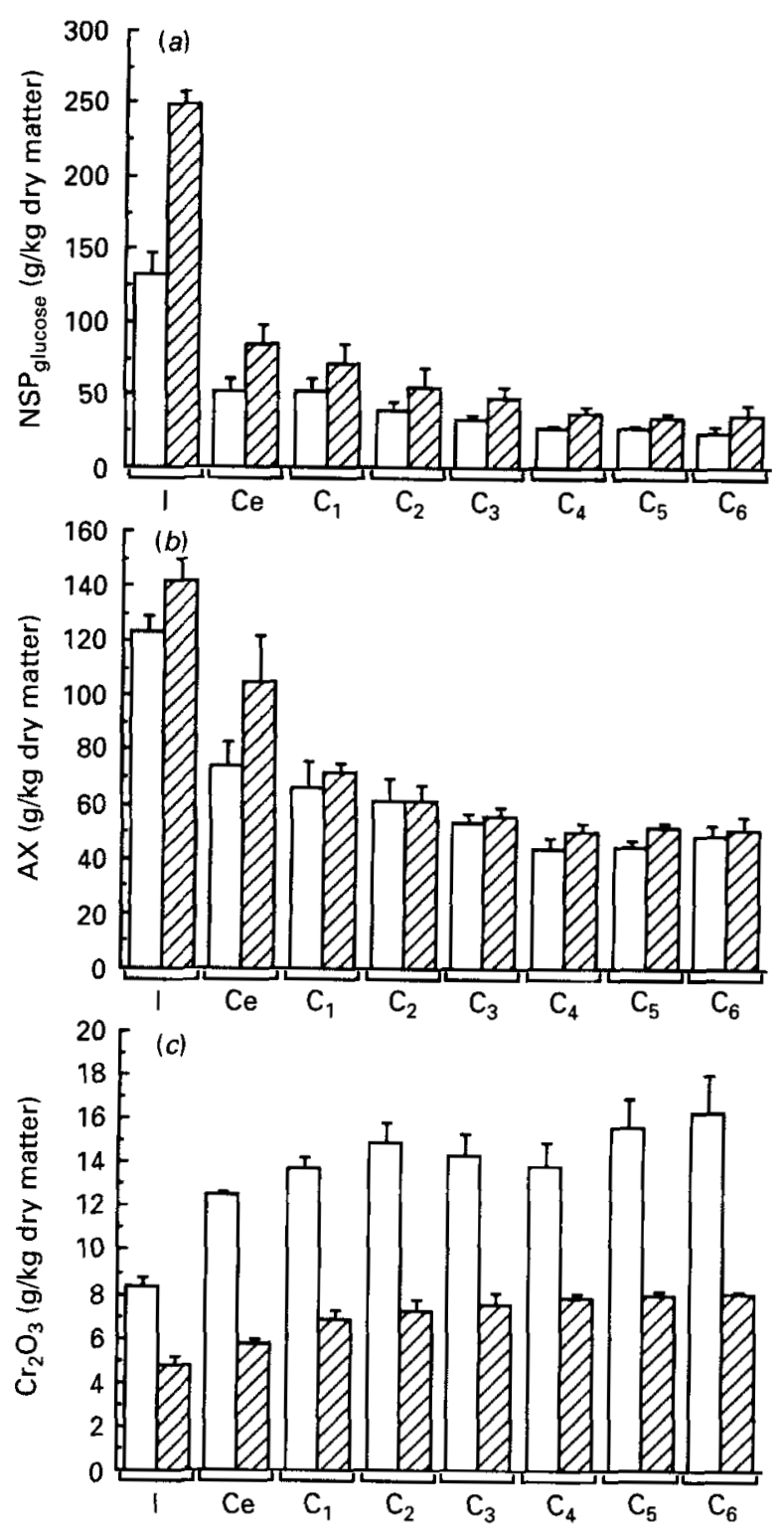

Fig. 3. (a) Non-starch polysaccharide-glucose (NSP ${ }_{\text {glucose }}$ ), $(b)$ arabinoxylans (AX) and chromic oxide marker concentration $(\mathrm{g} / \mathrm{kg}$ dry matter) in the gastrointestinal content of pigs fed on oat flour 1 ( $\square$ ) and oat bran (巴) diets. The various segments of the gastrointestinal tract were: I, ileum; Ce, caecum; $\mathrm{C}_{1}$, proximal colon; $\mathrm{C}_{2}$ and $\mathrm{C}_{3}$, ascending coion; $\mathrm{C}_{4}$ and $\mathrm{C}_{5}$, descending colon; $\mathrm{C}_{6}$, distal colon. Values are means of four pigs with their standard error of means represented by vertical bars. For details of diets, see Tables 1 and 3 .

intestinal segments were: diet $B-0.03$, diet D 0.02 . In the ileum digestibility was 0.30 and 0.17 with these two diets while in the caecum there was a significant degradation of $\beta$-glucan with digestibility values of 0.99 with diet $B$ and 0.92 with diet $D$.

Accumulation of polysaccharides and marker in digesta. The dietary level of $\beta$-glucan determines its concentration in the digesta. Despite the higher digestibility of nutrients in diet $\mathrm{B}$ compared with diet $\mathrm{D}$, the differences between the two diets in dietary $\beta$-glucan level 
Table 8. Net disappearance $(\mathrm{g} / \mathrm{d})$ of non-starch polysaccharides and nitrogen in caecum and various segments of colon of pigs fed on diets composed of various oat fractions

(Mean values for four pigs)

\begin{tabular}{|c|c|c|c|c|c|c|}
\hline \multirow[b]{2}{*}{$\operatorname{Diet}^{*} \ldots$} & \multicolumn{3}{|c|}{$\begin{array}{c}\text { Non-starch } \\
\text { polysaccharides }\end{array}$} & \multicolumn{3}{|c|}{$\mathrm{N}$} \\
\hline & B & $\mathrm{D}$ & SEM & B & $\mathrm{D}$ & SEM \\
\hline Caecum & $40^{\mathrm{b}}$ & $100^{\mathrm{a}}$ & 8.7 & $1 \cdot 3$ & -0.2 & $0 \cdot 6$ \\
\hline Colon 1 & $3^{\mathbf{b}}$ & $22^{\mathrm{a}}$ & $3 \cdot 5$ & 0.7 & $1 \cdot 3$ & 0.9 \\
\hline Colon 2 & 4 & 9 & 1.7 & 0.7 & 0.6 & $0 \cdot 2$ \\
\hline Colon 3 & 1 & 6 & 3.4 & $-0 \cdot 1$ & $0 \cdot 4$ & 0.2 \\
\hline Colon 4 & i & 6 & 1.8 & $-0 \cdot 2$ & 0.8 & 0.6 \\
\hline Colon 5 & $\hat{1}$ & $<1$ & $1 \cdot 3$ & $0 \cdot 4$ & $0 \cdot 3$ & 0.4 \\
\hline Colon 6 & $<1$ & $<1$ & $2 \cdot 0$ & 0.4 & 0.2 & $0 \cdot 3$ \\
\hline
\end{tabular}

a.b Values in the same horizontal row for non-starch polysaccharides with unlike superscript letters were significantly different $(P<0 \cdot 05)$.

NSP, non-starch polysaccharides; Colon 1, proximal colon; colon 2 and colon 3 , ascending colon; colon 4 and colon 5, descending colon; colon 6 , distal colon.

* For details of diets, see Tables 1 and 3.

were maintained throughout all segments of the upper GI tract (Fig. 2). The concentration of the $\mathrm{Cr}_{2} \mathrm{O}_{3}$ marker shows a more rapid digestion of the nutrients in diet $\mathrm{B}$ compared with diet D (Fig. 2). At $\mathrm{SI}_{2}$ the concentration of $\mathrm{Cr}_{2} \mathrm{O}_{3}$ was $4.03 \mathrm{~g} / \mathrm{kg}$ DM which was 3.4 times the level with diet $B$, while the concentration at this site only was twice $(2.39 \mathrm{~g} / \mathrm{kg} \mathrm{DM})$ the dietary level with diet $\mathrm{D}$.

Total NSP glucose values ( $\beta$-glucan and cellulose) in digesta from diets B and D respectively decreased from 132 and $249 \mathrm{~g} / \mathrm{kg} \mathrm{DM}$ in ileal digesta to 52 and $85 \mathrm{~g} / \mathrm{kg}$ DM in digesta from

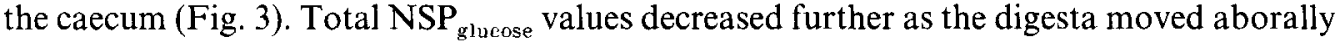
with values in the distal colon $\left(\mathrm{C}_{6}\right)$ of $25-36 \mathrm{~g} / \mathrm{kg}$ DM for the two diets. Only trace levels of $\beta$-glucan were detected in the colon contents indicating that $\mathrm{NSP}_{\text {glucose }}$ beyond the proximal colon $\left(\mathrm{C}_{1}\right)$ primarily represented cellulytic materials. AX was more slowly degraded than $\mathrm{NSP}_{\text {glucose }}$. The decrease in $\mathrm{AX}$ from the ileal to caecal digesta was from 123 to $74 \mathrm{~g} / \mathrm{kg} \mathrm{DM}$ with diet B and from 142 to $105 \mathrm{~g} / \mathrm{kg} \mathrm{DM}$ with diet D. In the distal colon there was a further decrease to 48 (diet B), and $51 \mathrm{~g} / \mathrm{kg} \mathrm{DM}$ (diet D).

Insoluble $\mathrm{Cr}_{2} \mathrm{O}_{3}$ marker increased significantly in the caecum and proximal colon from 8.3 and $4.8 \mathrm{~g} / \mathrm{kg} \mathrm{DM}$ in ileal contents to 13.7 and $6.8 \mathrm{~g} / \mathrm{kg} \mathrm{DM}$ in the proximal colon for diets $\mathrm{B}$ and $\mathrm{D}$ respectively. After that point the increase in marker concentration was much smaller with the concentration in the distal colon reaching $16.3 \mathrm{~g} / \mathrm{kg} \mathrm{DM}$ for diet $\mathrm{B}$ and $8.0 \mathrm{~g} / \mathrm{kg} \mathrm{DM}$ for diet $\mathrm{D}$.

Digestibility of polysaccharides and nitrogen in large intestine. NSP degradation in the caecum amounted to $40 \mathrm{~g} / \mathrm{d}$ with diet $\mathrm{B}$ and $100 \mathrm{~g} / \mathrm{d}$ with diet $\mathrm{D}$ (Table 8 ). In the proximal and first ascending colon $\left(\mathrm{C}_{1}\right.$ and $\left.\mathrm{C}_{2}\right)$ respectively, the net disappearance of NSP was 3 and $4 \mathrm{~g} / \mathrm{d}$ with diet $\mathrm{B}$ and 22 and $9 \mathrm{~g} / \mathrm{d}$ with diet $\mathrm{D}$. Less than $4 \mathrm{~g} / \mathrm{d}$ disappeared beyond $\mathrm{C}_{2}$ with diet $\mathrm{B}$ while with diet $\mathrm{D}$ net disappearance amounted to $14 \mathrm{~g} / \mathrm{d}$.

The total amount of $\mathrm{N}$ which disappeared in the large intestine of pigs fed on diets $\mathrm{B}$ and $\mathrm{D}$ was about the same (Table 8). However, when feeding diet $\mathrm{B}$ most $\mathrm{N}$ disappeared in the caecum and the two first segments of the colon (proximal and first ascending). When feeding diet $\mathrm{D}$ the $\mathrm{N}$ balance in the caecum was close to zero while there was a net disappearance in all segments of the colon. 


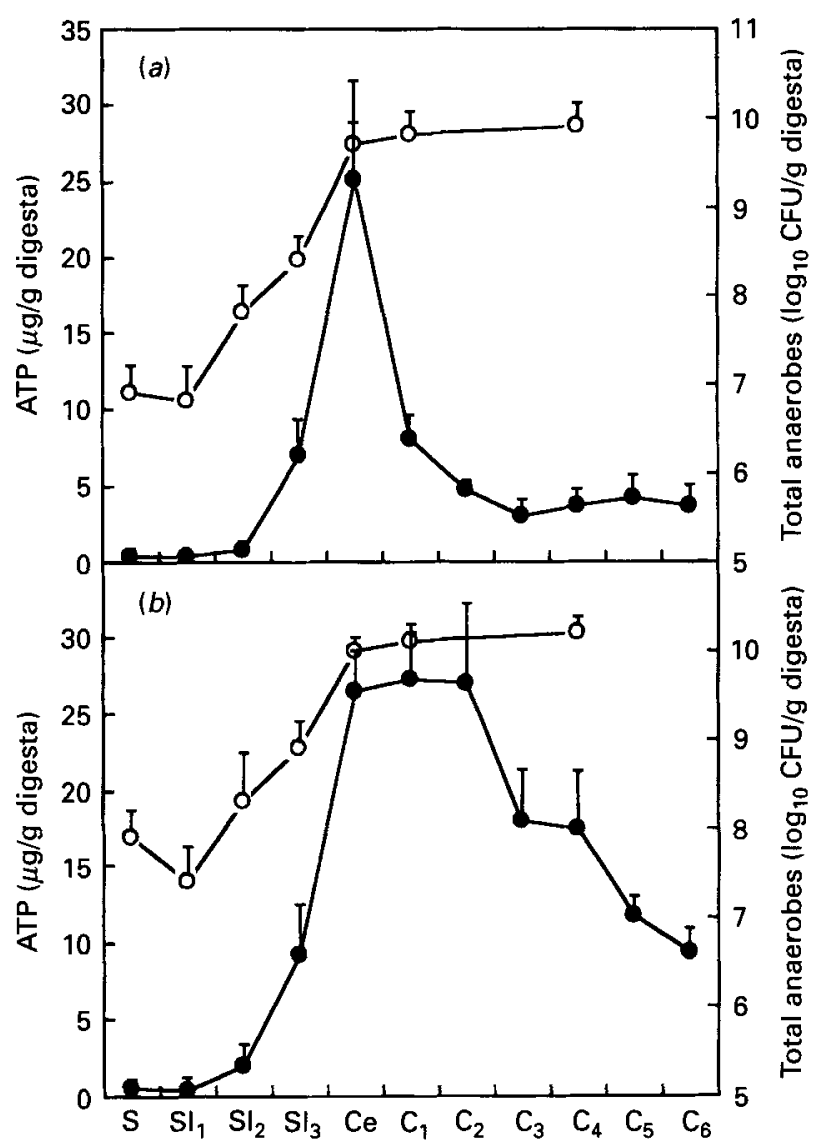

Fig. 4. Adenosine $5^{\prime}$-triphosphate concentration $(0 ; \mu \mathrm{g} / \mathrm{g}$ digesta) and total viable counts of anaerobic microorganisms $\left(O ; \log _{10} \mathrm{CFU} / \mathrm{g}\right.$ digesta) in gastrointestinal content of pigs fed on $(a)$ oat flour 1 and $(b)$ oat bran diets. The various segments of the gastrointestinal tract were: $\mathrm{S}$, stomach; $\mathrm{SI}_{1}, \mathrm{SI}_{2}$, and $\mathrm{SI}_{3}$, three equal segments of the small intestine; $\mathrm{Ce}$, caecum; $\mathrm{C}_{1}$, proximal colon; $\mathrm{C}_{2}$ and $\mathrm{C}_{3}$, ascending colon; $\mathrm{C}_{4}$ and $\mathrm{C}_{5}$, descending colon; $\mathrm{C}_{6}$, distal colon. Values are means of four pigs with their standard error of means represented by vertical bars. For details of diets, see Tables 1 and 3.

Microbial activity. The density of total culturable bacteria in the stomach and the cranial third of the small intestine was approximately $10^{7}$ viable counts/g digesta and increasing to $10^{8}-10^{9}$ viable counts/g digesta in the distal third (Fig. 4). In the caecum total culturable bacteria increased to $0.5-1.0 \times 10^{10}$ and further to $0.7-1.2 \times 10^{10}$ and $0.8-1.5 \times 10^{10}$ viable counts/g digesta in the proximal $\left(\mathrm{C}_{1}\right)$ and mid $\left(\mathrm{C}_{4}\right)$ colon. The concentration of ATP in the digesta was also low in the stomach and in the cranial two-thirds of the small intestine $(0 \cdot 2-2 \cdot 0 \mu \mathrm{g} / \mathrm{g}$ digesta) but increased significantly in the distal third $(7 \cdot 0-9 \cdot 2 \mu \mathrm{g} / \mathrm{g}$ digesta). In the caecum there was a rapid increase in ATP concentration to $25 \cdot 2-26.5 \mu \mathrm{g} / \mathrm{g}$ digesta. This level was maintained in the proximal $(27.3 \mu \mathrm{g} / \mathrm{g}$ digesta) and first ascending $(27.0 \mu \mathrm{g} / \mathrm{g}$ digesta) colon segments for the pigs fed on diet $\mathrm{D}$, while there was a decrease to 8.1 and $4.7 \mu \mathrm{g} / \mathrm{g}$ digesta in these two colon segments in the pigs on diet B. Beyond the second descending colon the ATP concentration was $3 \cdot 0-4 \cdot 2 \mu \mathrm{g} / \mathrm{g}$ digesta for the pigs on diet $B$, while the decrease on diet $D$ was from $18.0\left(C_{3}\right)$ to $9.3 \mu \mathrm{g} / \mathrm{g}$ digesta $\left(C_{6}\right) . A E C$ in caecal contents were the same for the two diets $(0.73-0.74)$. With diet $\mathrm{B}$, however, AEC decreased to 0.52 in the proximal colon and further to $0.34-0.42$ in the more distal colon 

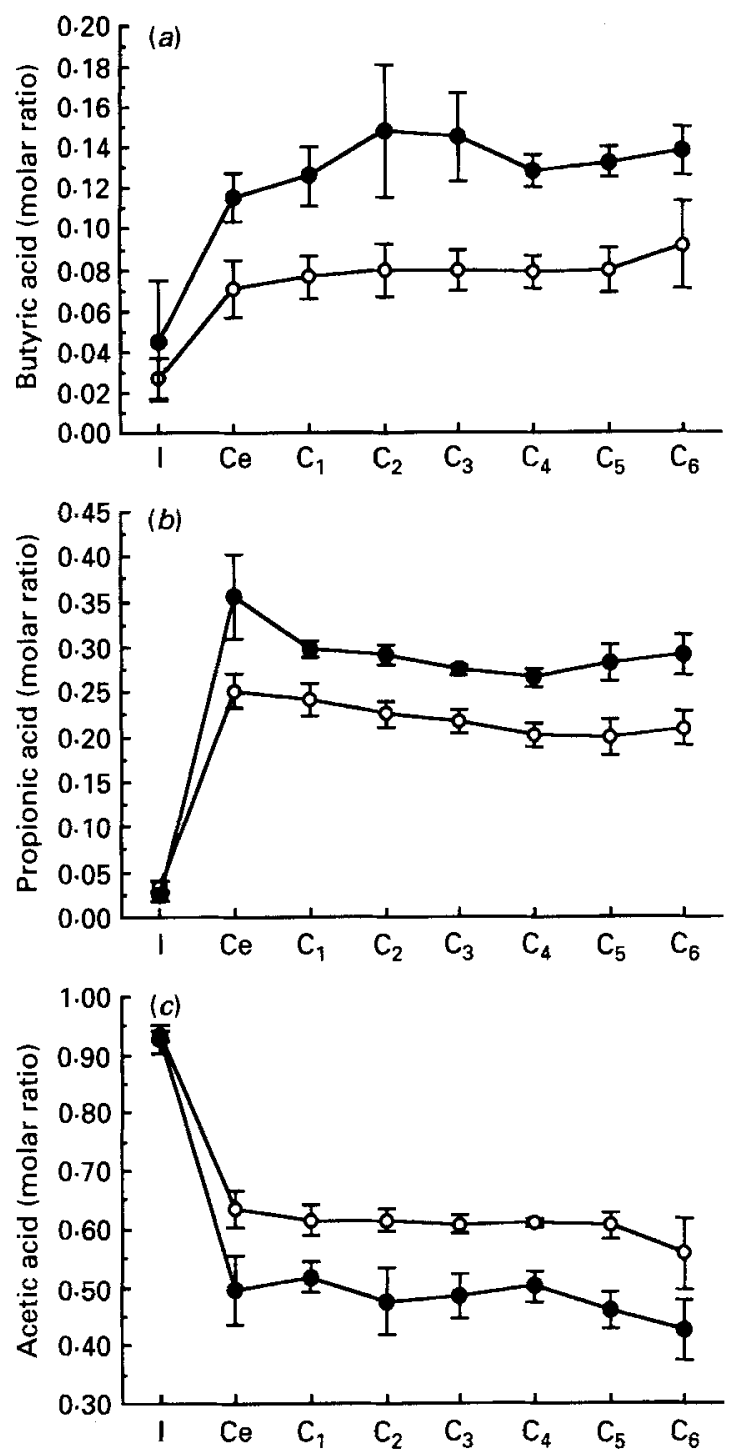

Fig. 5. Molar ratios of short-chain fatty acids: (a) butyric, $(b)$ propionic and $(c)$ acetic acids in the gastrointestinal contents of pigs fed on oat flour $1(\square)$ and oat bran $(\square)$ diets. The various segments of the gastrointestinal tract were: $I$, ileum; Ce, caecum; $C_{1}$, proximal colon; $C_{2}$ and $C_{3}$, ascending colon; $C_{4}$ and $C_{5}$, descending colon; $C_{6}$, distal colon. Values are means of four pigs with their standard error of means represented by vertical bars. For details of diets, see Tables 1 and 3 .

segments, while with diet D AEC was higher in all segments of the colon: 0.61 in the proximal colon, $0.73-0.76$ in the ascending colon, $0.57-0.59$ in the descending colon and 0.55 in the distal colon.

Organic acids. The concentration of SCFA was $2-9 \mathrm{mmol} / \mathrm{l}$ and that of LA was $3-18 \mathrm{mmol} / 1$ in the stomach and the cranial two-thirds of the small intestine. SCFA increased to $22-25 \mathrm{mmol} / 1$ and $\mathrm{LA}$ to $21-25 \mathrm{mmol} / 1$ in the distal third of the small intestine. In the caecum and proximal colon SCFA increased to $85-116 \mathrm{mmol} / \mathrm{l}$ while LA decreased to $3-6 \mathrm{mmol} / \mathrm{l}$. SCFA varied between $56-95 \mathrm{mmol} / \mathrm{l}$ while the concentration of 
LA was lower than $1 \mathrm{mmol} / \mathrm{l}$ in the ascending, descending and distal colon segments. Neither SCFA nor LA in all GI segments differed between diets.

The proportions of acetic, propionic and butyric acids in ileal digesta from the two diets was: acetic, 0.93; propionic, 0.03 and butyric, 0.03-0.05 (Fig. 5). In the large intestine the relative proportions of SCFA changed significantly with the diet. When feeding diet $\mathrm{B}$ the proportions of the three acids in the caecum and colon respectively was: acetic 0.64 , $0.56-0.61$; propionic $0.25,0.20-0.24$; butyric $0.07,0.07-0.09$, while on diet $\mathrm{D}$ the corresponding values were: acetic $0.50,0.42-0.52$; propionic $0.35,0.27-0.30$; butyric 0.12 , $0 \cdot 13-0 \cdot 15$. The branched-chain fatty acids, isobutyric and isovaleric, were also higher in digesta from all segments of the large intestine when feeding diet $\mathrm{B}$ compared with diet $\mathrm{D}$. In the ileal digesta the proportions of isobutyric and isovaleric acids were 0.000-0.001 and $0.002-0.001$ respectively. In the large intestine there was a steady increase in isobutyric and isovaleric acids respectively from 0.008 and 0.01 in the caecum to 0.04 and 0.06 in the distal colon when feeding diet B and from 0.00 and 0.003 in the caecum to 0.04 and 0.05 in the distal colon when feeding diet $\mathrm{D}$.

\section{DISCUSSION}

All the oat fractions used in the current study had a low concentration of cellulose and lignin. This was a result of the dehulling procedure, where the DF-rich husk was removed before the production of oat bran. As shown by Nyman \& Asp (1988), the husk of oats is very rich in lignin and insoluble NSP in the form of cellulose and AX. The milling process which was employed when producing oat bran effectively concentrated the aleurone and subaleurone cell-wall tissues in the bran fraction (Wood, 1986; Wood et al. 1989). This milling technique, however, is standardized less well than the conventional milling procedure used for wheat bran. Oat bran is, therefore, more variable with regard to composition than is wheat bran. The $\beta$-glucan content of the oat brans used in the present study was, however, higher than that contained in the definition for oat bran adopted by an AACC committee (Anonymous, 1989).

Lumen viscosity and intact cell-wall materials are two factors which are postulated to influence the delivery of glucose to the enterocyte (Jenkins et al. 1987). The results of the present study indicate that the presence of intact cell-wall materials from oat bran may play a significant role for the hypoglycaemic effect of oat bran. As judged from the lower digestibility of starch in the upper small intestine and the relatively low digestibility of AX, protein and fat at the end of the small intestine, we are tempted to believe that the thick aleurone and subaleurone cell-walls which are concentrated in the bran fraction retain their integrity and $\beta$-glucan content and thereby act as barriers against digestive enzymes. This could slow the rate of starch digestion without affecting the digestibility of starch. Further support for this assumption is the more rapid rise in marker concentration in the middle section of the small intestine when feeding the flour compared with the bran diet. While the effect of intact cell-wall materials on the rate of starch digestion is speculative, the significantly lower digestibility of protein and fat seen when the aleurone and subaleurone cell-wall materials replace endosperm cell walls (oat flour $1 v$. oat bran) is definitively a result of intact cell walls trapping nutrients. In an earlier investigation at this institute with mill fractions from barley the aleurone cell-wall materials of barley were shown to have similar properties (Bach Knudsen \& Eggum, 1984).

The relatively long small intestine of the pig ensures an efficient digestion of starch polysaccharides and neither oat bran nor the inclusion of other soluble or insoluble DF sources (Graham et al. 1986a; Bach Knudsen \& Hansen, 1991) result in malabsorption of starch in the small intestine. The relatively high ileal density of micro-organisms compared with the level in the stomach and cranial two-thirds of the small intestine, however, results 
in a significant degradation of $\beta$-glucan in the terminal ileum. AX is more resistant to digestion at this site of the gastrointestinal tract, probably due to its branched structure which makes it less prone to microbial degradation. For reasons unknown the digestibility of $\beta$-glucan $(0.17-0.28)$ was lower in the present study than that found in an earlier investigation (0.64-0.73; Bach Knudsen \& Hansen, 1991), whereas there was a less marked difference in the degradation of AX.

The variation in the reported precaecal digestion of $\beta$-glucan in cereals is significant, with values for $\beta$-glucan in oats ranging from 0.17 (present study) to 0.73 (Bach Knudsen \& Hansen, 1991) and in barley from 0.70 to 0.97 (Graham et al. 1986 b; Fadel et al. 1988, 1989). The variation in the digestibility values reported by various groups, however, is probably confounded by 'institute' differences in the technique used for digestibility estimations in pigs. In our studies we have consistently used pigs weighing $40-50 \mathrm{~kg}$ and fed on a DM level of approximately $40 \mathrm{~g} / \mathrm{kg}$ body weight while several of the studies with barley have used $80 \mathrm{~kg}$ pigs fed on DM at only $15 \mathrm{~g} / \mathrm{kg}$ body weight. A consequence of a lower feeding level could be a longer retention time of the residues in the small intestine and, thus, a prolonged exposure of digesta for microbial fermentation in the distal small intestine. In studies with older pigs higher digestibility values for $\beta$-glucan are consistently found (0.85-0.97; Fadel et al. 1988, 1989).

The digestibility of oat NSP in the large intestine was high and in agreement with values found with other non-lignified DF sources such as wheat flour (Bach Knudsen \& Hansen, 1991), pectins (Nyman \& Asp, 1982), sugar-beet pulp (Graham et al. 1986a) and guar gum (Nyman \& Asp, 1982). The lower digestibility of AX compared with that of $\beta$-glucan in the oat fractions is probably related to structural differences between the two polysaccharides. This has a direct consequence for the bulking properties of oat DF which are significantly lower than those for many other cereal DF sources, including the most commonly-used wheat bran (Nyman \& Asp, 1982; Bach Knudsen \& Hansen, 1991). In addition, oat DF affects the composition of faecal bulk in a different way. While wheat DF increases faecal DM excretion mainly by its physical presence (Bach Knudsen \& Hansen, 1991), the bulk of oat DF is digested, resulting in an increased excretion of protein and fat, presumably of bacterial origin.

The importance of feed composition for the process of fermentation in the large intestine is clearly demonstrated when combining the data for the quantitative flow of nutrients through terminal ileum, the net disappearance of nutrients within the various segments of the large intestine and the microbial data. In the present study there was a close correlation between the intake of DF and the amount of carbohydrates (NSP), fat and protein which escaped digestion in the small intestine. In the large intestine the net disappearance of carbohydrates was positively correlated with DF intake, while the disappearance of fat and protein was independent of DF intake. Hence, these findings together with another recent study (Bach Knudsen et al. 1991) point to the carbohydrates as the most important fuel for the microflora in the large intestine.

The caecum and the proximal and ascending colon are the most important sites of the large intestine for microbial degradation of carbohydrates as more than $92 \%$ of all the carbohydrates are degraded within these segments. It is also evidentially clear from the present study that the activity of the microflora in the colon respond to the energy supply. Although the density of bacteria in the caecum and colon is quite constant, $10^{10}-10^{11}$ viable counts/g digesta, the activity of the microflora (ATP and AEC) declined much more rapidly in the colon on the energy-scarce flour diet than on the bran diet. At the state of energy limitation the $\mathrm{C}$ skeleton from deamination of amino acids is used as an energy source and $\mathrm{NH}_{3}$ is absorbed by the host, but when energy is sufficient $\mathrm{NH}_{3}$ is built into microbial biomass. This conclusion is supported by the $\mathrm{N}$ data from the caecum. When the 
pigs were fed on the flour diet there was $\mathrm{N}$ degradation of $1.3 \mathrm{~g} \mathrm{~N} / \mathrm{d}$ in the caecum, while on the bran diet $\mathrm{N}$ balance was close to zero. However, when digesta moves aborally and energy became a limiting factor for the microflora on the bran diet there was a net degradation of $\mathrm{N}$. Moreover, energy limitation is also responsible for the more rapid rise in the proportion of branched-chain fatty acids of SCFA when feeding the flour diet compared with the bran diet. Branched-chain fatty acids are derived from breakdown of branched-chain amino acids by fermentation (Macfarlane et al. 1986). In caecal contents of pigs fed on the flour diet isobutyric and isovaleric acid levels were 0.008 and 0.010 , but when feeding the bran diet the values were 0.000 and 0.002 respectively.

The SCFA produced are rapidly absorbed from the gut lumen (Argenzio \& Whipp, 1979). The net disappearance of carbohydrates together with the theoretical production of SCFA given by Miller \& Wolin (1979) indicate that the production of SCFA within the caecum may reach approximately $1100 \mathrm{mmol} / \mathrm{d}$, derived from degradation of $100 \mathrm{NSP} / \mathrm{d}$ and $9 \mathrm{~g}$ starch + sugars $/ \mathrm{d}$. There was no difference between the two diets in the concentration of SCFA in this segment of the large intestine. The type of acids formed, however, depends of the composition of available nutrients. When residues of oat bran were the substrate for the microflora instead of oat flour the theoretical production of butyric acid (mmol/kg fermented carbohydrates) increased from 790 to 1330. Similar results have been obtained in studies where oat products replaced wheat products (Bach Knudsen et al. 1991). At the present time we can only speculate about the tendency towards enhanced butyric acid production, but factors such as the chemical composition of substrate and the growth rate of the microflora are two important factors which are known to influence product formation during fermentation (Salyers \& Leedle, 1983). Since the proportions of the major SCFA are constant from the caecum to the distal colon it seems unlikely that the higher content of $\beta$-glucan in fermented NSP from bran compared with flour is responsible for the higher production of butyric acid.

The present study confirms that oat diets varying widely in $\beta$-glucan content affect several events in the gastrointestinal tract. Oat bran, because of the cell walls trapping nutrients, reduced the digestibility of oat protein and fat in the small intestine while there was no effect on the digestibility of starch. The study also revealed that the caecum and proximal and ascending colon are the most important segments of the large intestine for carbohydrate fermentation. The type and amount of residues passing the ileo-caecal junction have no effect on the density of micro-organisms in the colon but do have a strong impact on the activity and the pattern of fermentation in the colon.

This work was supported by the Danish Agricultural and Veterinary Research Council. The authors are indebted to Lars Munck, Department of Biotechnology, Carlsberg Research Laboratory, Denmark for placing the milling facility at our disposal. They would also like to thank Henry Jørgensen for carrying out the surgery, Kirsten Ditlev Østergaard and Hanne Lund Jensen for excellent technical assistance and Bjørn O. Eggum for his advice during the course of the work.

\section{REFERENCES}

Anderson, J. W. (1990). Hypocholesterolemic effects of oat products. In New Developments in Dietary Fiber: Physiological, Physicochemical and Analytic Aspects, pp. 17-36 [I. Furda and C. J. Brine, editors]. New York: Plenum Publishing Corporation.

Anonymous (1989). AACC committee adopts oat bran definition. Cereal Food World 34, 1033-1034.

Argenzio, R. A. \& Whipp, S. C. (1979). Inter-relationship of sodium, chloride, bicarbonate and acetate transport by the colon of the pig. Journal of Physiology 195, 365-381.

Association of Official Analytical Chemists (1975). Official Methods of Analysis, 11 th ed. Washington, DC: Association of Official Analytical Chemists. 
Bach Knudsen, K. E., Åman, P. \& Eggum, B. O. (1987). Nutritive value of Danish-grown barley varieties, I, Carbohydrates and other major constituents. Journal of Cereal Science 6, 173-186.

Bach Knudsen, K. E. \& Eggum, B. O. (1984). The nutritive value of botanically defined mill fractions of barley. 3. The protein and energy value of pericarp, Testa, germ, aleuron, and endosperm reic decortication fractions of the variety Bomi. Journal of Animal Physiology and Animal Nutrition 51, 130-148.

Bach Knudsen, K. E. \& Hansen, I. (1991). Gastrointestinal implications in pigs of wheat and oat fractions. 1. Digestibility and bulking properties of polysaccharides and other major constituents. British Journal of Nutrition 65, 217-232.

Bach Knudsen, K. E., Hansen, I., Jensen, B. B. \& Østergård, K. (1990). Physiological implications of wheat and oat dietary fiber. In New Developments in Dietary Fiber: Physiological, Physiochemical, and Analaytical Aspects pp. 135-150 [I. Furda and C. J. Brine, editors]. New York; Plenum Press.

Bach Knudsen, K. E., Jensen, B., Anderson, J. O. \& Hansen, I. (1991). Gastrointestinal implications in pigs of wheat and oat fractions. 2. Microbial activity in the gastrointestinal tract. British Journal of Nutrition $\mathbf{6 5}$, 233-248.

Bach Knudsen, K. E. \& Li, B. (1991). Determination of oligosaccharides in protein-rich feedstuffs by gas-liquid chromatography and high-performance liquid chromatography. Journal of Agricultural and Food Chemistry 39 , 689-694.

Chen, W. J. L. \& Anderson, J. W. (1986). Hypocholesterolemic effects of soluble fibers. In Dietary Fibre: Basic and Clinical Aspects, pp. 275-285 [G. V. Vahouny and D. Kritchevsky, editors]. New York: Plenum Press.

Englyst, H. N., Wiggins, H. S. \& Cummings, J. H. (1982). Determination of non-starch polysaccharides in plant foods by gas-liquid chromatography of constituent sugars as alditol acetates. Analyst 107, 307-318.

Fadel, J. G., Newman, C. W., Newman, R. K. \& Graham, H. (1988). Effects of extrusion cooking of barley on ileal and faecal digestibilities of dietary components in pigs. Canadian Journal of Animal Science 68, 891-897.

Fadel, J. G., Newman, R. K., Newman, C. W. \& Graham, H. (1989). Effects of baking hulless barley on the digestibility of dietary components as measured at the ileum and in feces in pigs. Journal of Nutrition 119 , $722-726$.

Graham, H., Hesselman, K. \& Åman, P. (1986a). The influence of wheat bran and sugar-beet pulp on the digestibility of dietary components in a cereal-based pig diet. Journal of Nutrition 116, 242-251.

Graham, H., Hesselman, K., Jonsson, E. \& Åman, P. (1986 b). Influence of $\beta$-glucanase supplementation on digestion of a barley-based diet in the pig gastrointestinal tract. Nutrition Reports International 34, $1089-1096$.

Hansen, I., Larsen, T., Bach Knudsen, K. E. \& Eggum, B. O. (1991). Nutrient digestibilities in ingredients fed alone or in combinations. British Journal of Nutrition 66, 27-35.

Jenkins, D. J. A., Jenkins, A. L., Wolever, T. M., Collier, G. R., Rao, A. V. \& Thompson, L. U. (1987). Starchy foods and fibre: reduced rate of digestion and improved carbohydrate metabolism. Scandinavian Journal of Gastroenterology 22, 132-141.

Just, A. (1975). Feed evaluation in pigs. World Review of Animal Production ii, 18-30.

Kirby, R. W., Anderson, J. W., Sieling, B., Rees, E. D., Chen, W. J. L., Miller, R. E. \& Kay, R. M. (1981). Oatbran intake selectively lowers serum low-density lipoprotein cholesterol concentrations of hypercholesterolemic men. American Journal of Clinical Nutrition 34, 824-829.

Kowalski, R. E. (1987). The 8-Week Cholesterol Cure. New York: Harper \& Row, Publishers.

Larsson, K. \& Bengtsson, S. (1983). Bestämming av lättilgängeliga kolhydrater i växtmaterial (Determination of readily available carbohydrates in plant material). National Laboratory of Agricultural Chemistry Methods Report no. 22. Uppsala: National Laboratory of Agricultural Chemistry.

McCleary, B. V. \& Glennie-Holmes, M. (1985). Enzymic quantification of (1-3), (1-4)- $\beta$-D-glucan in barley and malt. Journal of the Institute of Brewing 91, 285-295.

Macfarlane, G. T., Cummings, J. H. \& Allison, C. (1986). Protein degradation by human intestinal bacteria. Journal of General Microbiology 132, 1647-1656.

Mathers, J. C. (1991). Digestion of non-starch polysaccharides by non-ruminant omnivores. Proceedings of the Nutrition Society 50, 161 172.

Miller, T. L. \& Wolin, M. J. (1974). A serum bottle modification of the Hungate technique for cultivating obligate anaerobes. Applied Microbiology 27, 985-987.

Miller, T. L. \& Wolin, M. J. (1979). Fermentation by saccharolytic intestinal bacteria. American Journal of Clinical Nutrition 32, 164-172.

Nyman, M. \& Asp, N.-G. (1982). Fermentation of dietary fibre components in the rat intestinal tract. British Journal of Nutrition 47, 357-366.

Nyman, M. \& Asp, N.-G. (1988). Fermentation of oat fiber in the rat intestinal tract: a study of different cellular areas. American Journal of Clinical Nutrition 48, 274-278.

Salyers, A. A. \& Leedle, J. A. Z. (1983). Carbohydrate metabolism in the human colon. In Human Intestinal Microflora in Health and Disease, pp. 129-146 [D. J. Hedges, editor]. New York: Academic Press.

Schürch, A. F., Lloyd, L. E. \& Crampton, E. W. (1950). The use of chromic oxide as an index for determining the digestibility of a diet. Journal of Nutrition $\mathbf{5 0}, 628-636$.

Snedecor, G. W. \& Cochran, W. G. (1973). Statistical Methods. Ames: Iowa State University Press.

Stoldt, W. (1952). Vorschlag zur Vereinheitlichung der Fettbestimmung in Lebensmitteln (Suggestion to standardize the determination of fat in food stuffs). Fette, Seifen, Anstrichmittel 54, $206-207$. 
Theander, O. \& Åman, P. (1979). Studies on dietary fibre. 1. Analysis and chemical characterization of watersoluble and water-insoluble dietary fibres. Swedish Journal of Agricultural Research 9, 97-106.

Theander, O. \& Westerlund, E. A. (1986). Studies on dietary fiber. 3. Improved procedures for analysis of dietary fiber. Journal of Agricultural and Food Chemistry 34, 330-336.

Wood, P. J. (1986). Oat $\beta$-glucan: Structure, location, and properties. In Oats: Chemistry and Technology, pp. 121-152 [F. H. Webster, editor]. St Paul: American Association of Cereal Chemists.

Wood, P. J., Weisz, J., Fedec, P. \& Burrows, V. D. (1989). Large-scale preparation and properties of oat fractions enriched in $(1 \rightarrow 3)(1 \rightarrow 4)-\beta$-D-glucan. Cereal Chemistry 66, 97-103.

Yiu, S. H., Wood, P. J. \& Weisz, J. (1987). Effects of cooking on starch and $\beta$-glucan of rolled oats. Cereal Chemistry 64, 373-379. 